\title{
Structural dynamic of social wasp communities (Hymenoptera: Vespinae) in forest areas destroyed by acid rains in the Karkonosze Mountains
}

\author{
Tadeusz Pawlikowski
}

Laboratory of Biomonitoring of Terrestrial Environments, Institute of Ecology and Protection of Environment, Nicolaus Copernicus University, Gagarina 9, 87-100 Toruń, Poland

e-mail: pawlik@umk.pl

\begin{abstract}
The structure of the social wasp communities was studied in the forest areas of the Karkonosze Mts. transformed by acid rains in 1989 and 1994. A significant increase of species diversity (H') was observed in the season of the even year, which resulted from the increased competing interactions between queen mothers. Whereas the distribution of the species' number decreased together with the altitude proportionally to natural distribution of the species' number recorded in the Tatra Mts. On the other hand, the only significantly increased value in the dynamics of Vespinae density in vegetation zones of the Karkonosze Mts. was recorded for the lower subalpine forest. While observing the progressing successive restoration of forests, one can assume that the recorded structural changes in communities of social wasps represent their transitional state.
\end{abstract}

Key words: Hymenoptera, Vespinae, social wasps, communities, forests, Karkonosze Mts.

\section{Introduction}

Structural changes in communities of predatory and mellitophagous social hymenopterans depend mainly on nutritional resources and climate-forming spatial organization of vegetation in an ecosystem. Directionality of these changes was tentatively defined in the environments of eastern Karkonosze Mts. and an attempt was undertaken to use them for the assessment of the transformation extent in the mountain environments (Pawlikowski 1993). So far no research was conducted on this aspect in the mountain landscape of the whole range of the Karkonosze Mts.

The main mechanism behind the development of the structure of the social wasp communities is an intrapopulation cycle of two-year quantitative changes as predicted by Archer (1998) and connected with competition between queen mothers for habitat resources during their nesting (Pawlikowski \& Pawlikowski 2006). This mechanism remains under the strong influence of climatic conditions, which in mountains definitively modifies by the vegetation. From among different types of vegetation, thicket and tall-forb vegetation is the most favourable for the development of social wasps' nests (Pawlikowski \& Osmański 1998).

During the 1990s of the last century, degradation of forests in the Karkonosze Mts. intensified. As a consequence of inappropriate forest management in the past, as well as under the influence of post-industrial acidified precipitation, mass extinction of forests followed. As a further consequence of this phenomenon, clearings of dead tree stands commenced, which changed the natural composition of forests in Karkonosze Mts. And thus, fragmentation of those forest areas began to proceed quickly, and together with this, xerisation of the environment. Substitute thickets and tall forb communities encroached onto clearings and dead spruce-tree stands thinned out by windthrows.

The present paper constitutes an attempt to determine the structural changes of social wasp communities in forest 
Table 1. Domination of Vespinae wasps in floors of vegetation of the Karkonosze Mts. in 1989 (according to Pawlikowski 1993) and 1994

\begin{tabular}{|c|c|c|c|c|c|c|c|c|c|c|c|c|c|c|c|c|c|c|}
\hline \multirow{4}{*}{ Species } & \multicolumn{18}{|c|}{ Floors of vegetation } \\
\hline & \multirow{2}{*}{\multicolumn{2}{|c|}{$\begin{array}{c}\text { FH } \\
\begin{array}{c}1989 \\
n=10\end{array}\end{array}$}} & \multicolumn{4}{|c|}{$\mathrm{LF}$} & \multicolumn{4}{|c|}{ UF } & \multicolumn{4}{|c|}{$\mathrm{SF}$} & \multicolumn{4}{|c|}{$\mathrm{AF}$} \\
\hline & & & \multicolumn{2}{|c|}{$\begin{array}{c}1989 \\
n=10\end{array}$} & \multicolumn{2}{|c|}{$\begin{array}{c}1994 \\
n=12\end{array}$} & \multicolumn{2}{|c|}{$\begin{array}{c}1989 \\
n=10\end{array}$} & \multicolumn{2}{|c|}{$\begin{array}{l}1994 \\
n=8\end{array}$} & \multicolumn{2}{|c|}{$\begin{array}{c}1989 \\
n=10\end{array}$} & \multicolumn{2}{|c|}{$\begin{array}{l}1994 \\
n=6\end{array}$} & \multicolumn{2}{|c|}{$\begin{array}{c}1989 \\
n=10\end{array}$} & \multicolumn{2}{|c|}{$\begin{array}{l}1994 \\
n=5\end{array}$} \\
\hline & $\mathrm{n}_{\mathrm{i}}$ & $\% \mathrm{~N}$ & $\mathrm{n}_{\mathrm{i}}$ & $\% \mathrm{~N}$ & $n_{i}$ & $\% \mathrm{~N}$ & $\mathrm{n}_{\mathrm{i}}$ & $\% \mathrm{~N}$ & $\mathrm{n}_{\mathrm{i}}$ & $\% \mathrm{~N}$ & $\mathrm{n}_{\mathrm{i}}$ & $\% \mathrm{~N}$ & $\mathrm{n}_{\mathrm{i}}$ & $\% \mathrm{~N}$ & $n_{i}$ & $\% \mathrm{~N}$ & $n_{i}$ & $\% \mathrm{~N}$ \\
\hline Vespa crabro L. & 1 & 1.1 & - & - & 2 & 0.8 & - & - & - & - & - & - & - & - & - & - & - & - \\
\hline Dolichovespula norvegica (F.) & - & - & 4 & 7.6 & - & - & 74 & 97.4 & - & - & 17 & 100 & - & - & 11 & 100 & 5 & 100 \\
\hline Dolichovespula saxonica (F.) & 47 & 54.0 & 18 & 34.6 & 121 & 47.6 & - & - & 8 & 21.6 & - & - & 9 & 100 & - & - & - & - \\
\hline Dolichovespula sylvestris (ScOP.) & 2 & 2.3 & - & - & - & - & - & - & - & - & - & - & - & - & - & - & - & - \\
\hline Vespula germanica $(\mathrm{F})$. & 8 & 9.2 & - & - & 15 & 5.9 & - & - & - & - & - & - & - & - & - & - & - & - \\
\hline Vespula rufa (L.) & 9 & 10.3 & - & - & - & - & - & - & - & - & - & - & - & - & - & - & - & - \\
\hline Vespula vulgaris (L.) & 20 & 22.9 & 30 & 57.7 & 116 & 45.7 & 2 & 2.6 & 29 & 78.4 & - & - & - & - & - & - & - & - \\
\hline Total number of specimens $[\mathrm{N}]$ & 87 & 100 & 52 & 100 & 254 & 100 & 76 & 100 & 37 & 100 & 17 & 100 & 9 & 100 & 11 & 100 & 5 & 100 \\
\hline
\end{tabular}

$\mathrm{FH}$ - foothills, LF - lower sprurce forest, UF - uper sprurce forest, SF - subalpine floor, AF - alpine floor, $n$-number of samples, $n_{i}$ - number of specimens

areas transformed by acid rains within the entire mountain range of Karkonosze Mts. Furthermore, the intention was to check the usefulness of the Vespinae community's structure for bioindication of the degradation extent of subalpine forests in the Karkonosze Mts.

\section{Materials and methods}

The research was conducted between July 3-23, 1989 in the eastern part of the Karkonosze Mts. and between August 15-29, 1994 in the western part of the Karkonosze Mts. Those were periods when the development of social wasps' nests was at its peak. Materials from the first research season were collected at 10 sites and then provisionally published (Pawlikowski 1993). Materials from the second research season were collected at 20 sites.

The sites were distributed within 5 vegetation zones described by Fabiszewski (1985): the foothills in the habitat of Galio-Carpinetum (FH) - 360-500 m asl; the lower subalpine forest, spruce forest in the habitat of Luzulo luzuloidus-Fagetum or Dentario enneaphyllidis-Fagetum (LF) - 500-1000 m; the upper subalpine forest, spruce forest in the habitat of Plagiothecio-Piceetum hercynicum (UF)
- 1200-1250 m; the subalpine zone together with the community of dwarf mountain pine Pinetum mughi sudeticum (SF) - 1250-1450 m; the alpine zone (mountain pastures) together with the community of Carici-Festucetum (AF) - above $1450 \mathrm{~m}$.

Sites of the second research season were located in the following vegetation zones: LF - 12 sites (WS33 Szklarska Poręba), UF - 3 sites (WS33 Czeska Ścieżka, environs of Łabski Szczyt, Kamieńczyk), SF - 2 sites (WS32 Łabski Szczyt, Three Świnki), AF - 1 site (WS32 a meteorological station near the Śnieżne Kotły Mts.).

The number of wasps caught and recorded during their activities (hunting, collection of nectar or honeydew) during half an hour penetration on the area of $2 \times 100 \mathrm{~m}$ or $4 \mathrm{x}$ $50 \mathrm{~m}$ with optimal weather conditions (10.00-17.00 CET, nice weather, air temperature of $19-25^{\circ} \mathrm{C}$ ) was assumed as a calculation unit (a sample). Wasps were identified to the species level, mainly in the field with the use of a handheld magnifying glass (x20), and released afterwards. A sample collected during half an hour was assumed to be the smallest representative size of the hunting ability (density) per $200 \mathrm{~m}^{2}$ (Pawlikowski 1990). The total number of collected samples and the total number of wasps recorded at the sites in the vegetation zones are presented in Table 1. 
Table 2. Characteristics of the Vespinae communities in floors of vegetation of the Karkonosze Mts. investigated in 1989 and 1994

\begin{tabular}{|c|c|c|c|c|c|c|c|c|c|}
\hline \multirow{3}{*}{ Parameters } & \multicolumn{9}{|c|}{ Floors of vegetation (as in Tab.1) } \\
\hline & \multirow{2}{*}{$\begin{array}{c}\mathrm{FH} \\
1989\end{array}$} & \multicolumn{2}{|c|}{ LF } & \multicolumn{2}{|c|}{ UF } & \multicolumn{2}{|c|}{ SF } & \multicolumn{2}{|c|}{$\mathrm{AF}$} \\
\hline & & 1989 & 1994 & 1989 & 1994 & 1989 & 1994 & 1989 & 1994 \\
\hline Number of species $[\mathrm{S}]$ & 6 & 3 & 4 & 2 & 2 & 1 & 1 & 1 & 1 \\
\hline Density [D] & 8.70 & 5.20 & 21.17 & 7.40 & 4.11 & 1.70 & 1.50 & 1.10 & 1.00 \\
\hline Tendency of D values [TD]* & - & \multicolumn{2}{|c|}{$\uparrow^{*}$} & \multicolumn{2}{|c|}{ ns } & \multicolumn{2}{|c|}{ ns } & \multicolumn{2}{|c|}{ ns } \\
\hline Diversity [H'] & 1.21 & 0.88 & 0.92 & 0.12 & 0.52 & 0 & 0 & 0 & 0 \\
\hline Tendency of H'values [TH']* & - & \multicolumn{2}{|c|}{$\uparrow *$} & \multicolumn{2}{|c|}{$\uparrow^{*}$} & \multicolumn{2}{|c|}{$=$} & \multicolumn{2}{|c|}{$=$} \\
\hline Evenness [J'] & 0.75 & 0.80 & 0.66 & 0,17 & 0.75 & 0 & 0 & 0 & 0 \\
\hline Tendency of J'values [TJ'] & - & \multicolumn{2}{|c|}{$\downarrow$} & \multicolumn{2}{|c|}{1} & \multicolumn{2}{|c|}{$=$} & \multicolumn{2}{|c|}{$=$} \\
\hline
\end{tabular}

$D$ - mean number of specimens per 30 min. per $200 \mathrm{~m}^{2}$; TD - tendency of D value changes with the significance level

$\mathrm{H}^{\prime}$ - Shannon index; $\mathrm{TH}^{\prime}$ - tendency of $\mathrm{H}^{\prime}$ value changes with the significance level

$\mathrm{J}^{\prime}$ - Pielou index; $\mathrm{TJ}^{\prime}$ - tendency of $\mathrm{J}^{\prime}$ value changes

value changes: $=-$ no changes, $\downarrow-$ decrease, $\uparrow-$ increase

${ }^{*}$ ) significance level $\mathrm{P} \leq 0.05$ : ns - not significance

All samples were used to develop the main parameters of the structure of social wasps' communities.

The structure of each community was described by the number of species (S), density expressed as an average number of individuals recorded during 30 min walk in the area of $200 \mathrm{~m}^{2}(\mathrm{D})$, the index of general species diversity $\left(\mathrm{H}^{\prime}\right)$ and the index of potential species diversity $(\mathrm{J})$. Differences between D values from particular years were statistically assessed with the t-test. The formula of the general species diversity index was accepted after Shannon \& Weaver (1963): $\mathrm{H}^{\prime}=-\sum p_{i} \log _{2} p_{i}$, where $p_{i}=n_{i} / N$ and denotes a fraction of the $i^{\text {th }}$ species in a community that consists of S species, and $\mathrm{n}_{\mathrm{i}}$ stands for the count of the $t^{\text {th }}$ species in a community with the total size of $\mathrm{N}$ individuals. The index of potential species diversity, also known as an index of evenness of qualitative species distribution in a community, accepted after Pielou (1966): J' $=\mathrm{H}^{\prime} / \log _{2} \mathrm{~S}$, where $\log _{2} \mathrm{~S}$ denotes a maximum value of the index $\mathrm{H}^{\prime}$ $\left(\mathrm{H}_{\max }{ }^{\prime}\right)$. The index $\mathrm{J}$ ' assumes values within the range of $0<\mathrm{J}^{\prime}<1$, while decreasing the value till 0 means the increasing tendency of super-domination, and increasing the value up to 1 means the increasing tendency of codomination. Statistical significance of differences between values of the index H' was assessed according to Hutcheson (1970) by applying estimation variance formulas and degrees of freedom for the assessment of differences between H' values (t-test). In all statistical comparisons, the significance of the difference (P) was accepted at the level equal and higher than 0.05 .

\section{Results}

At 30 locations in the Polish Karkonosze Mts., 648 specimens of 7 social wasp species were caught during two seasons (Tab. 1). Most of the individuals were collected at the foothills (FH) and in the lower subalpine forest (LF), fewer - in the upper subalpine forest (UF), and the least in the dwarf-pine zone (SF) and in the alpine-forest zone (AF). Average density (D) of social wasps in individual zones changed in the approximate ratio of $8(\mathrm{FH}): 5(\mathrm{LF})$ $:$ 7(UF) : 1.5(SF) : 1(AF) in 1989, and 21(LF) : 4(UF) : $1.5(\mathrm{SF}): 1(\mathrm{AF})$ in 1994 . A similar tendency of variability was revealed in the number of species (S) in the distinguished communities of wasps, i.e. $6(\mathrm{FH}): 3(\mathrm{LF}): 2(\mathrm{UF})$ $: 1(\mathrm{SF}): 1(\mathrm{AF})$ in 1989 , and $4(\mathrm{LF}): 2(\mathrm{UF}): 1(\mathrm{SF}): 1(\mathrm{AF})$ in 1994.

Habitat attractiveness (expressed by S and D) of vegetation zones from higher and higher altitude decreased up to the dwarf-pine zone and remained at the lowest level in the alpine-forest zone. Foothills and the lower subalpine forest, as relatively the most appealing zones, clearly differ in the species composition from other vegetation zones. In communities from $\mathrm{FH}$ and LF, the presence of species 
with a long life cycle was particularly evident: Vespa crabro L., Vespula germanica (F.), Vespula vulgaris (L.) as well as one species with a short life cycle - Dolichovespula saxonica (F.). In the less appealing zone of the upper subalpine forest no other species from the foothills were found, including the hornet $V$. crabro (a typical forest species). The dwarf-pine and alpine zones were the least attractive habitats. Only two wasp species a short life cycle were nesting there: D. saxonica and Dolichovespula norvegica (F.). However, they occurred in those habitats depending on conditions that enable them to build nests. The wasp $D$. saxonica builds mainly surface nests hung in various hiding places (most frequently in hollows or wooden anthropogenic facilities), and the wasp D. norvegica builds subterranean nests (Edwards 1980; Kemper \& Döhring 1967; Matsuura \& Yamane 1990). And thus, together with the altitude increase, there was observed a natural declining gradient of habitat attractiveness for social wasps. A similar picture of Vespinae distribution was observed in the Tatras (Pawlikowski 1997).

An average abundance of wasps per community ranged from 8.70 to 1.10 individuals during $30 \mathrm{~min}$ walk on the area of $200 \mathrm{~m}^{2}$ in the first season and 21.17-1.00 individuals in the second season. Therefore, it appears that the lowest values occurred in odd years, and the highest - in even years (Tab. 2). This was in accordance with the already described rule of changes in the size of the Vespinae community (Pawlikowski \& Pawlikowski 2006). Particular differences in seasonal count fluctuations were recorded in the zone LF.

Qualitative and quantitative characteristics of the structure of the each social wasp community were described by indices of general ( $\left.\mathrm{H}^{\prime}\right)$ and potential ( $\mathrm{J}$ ') species diversity (Tab. 2). It was found that the community structure persisted only up to the upper subalpine forest (inclusive). Within the higher zones, disintegration of the structure of the interactive species complex occurred and consequently only one species with very low density was recorded. Functionally the most efficient structure of the Vespinae community was recorded at the foothills and in the lower subalpine forest. In the season (1989) when the number of wasps in the community (according to Archer 1998) decreased as a result of no competition between queen mothers, significantly low values of general heterogeneity ( $\left.H^{\prime}\right)$ were recorded. Whereas, in the season (1994) when the number of wasps in a community increased as a result of competition between queen mothers, significantly higher values of general heterogeneity were observed. In the lower subalpine forest this was connected with the decrease of J', i.e. potential diversity (and thus with the increased participation of dominating species of a community), and in the upper subalpine forest - with the increase of potential diversity (i.e. with the decrease of dominating shares).

\section{Discussion}

Subalpine forests in the Karkonosze Mts., degraded by acid rains, became attractive habitats for xerothermic Vespinae. Making the subalpine forests more appealing meant mainly to increase the mosaic of warmer thicket and tall forb habitats favourable to the development of phyto- and saprophagous species of dipterans, potential victims of social wasps. Contrary to the degraded forests in the Karkonosze Mts., subalpine forests of the Tatras preserved its natural organization, against the background of which a proportional decrease in the number of species was recorded in the ratio of $3.5(\mathrm{FH}): 3(\mathrm{LF}): 2(\mathrm{UF}): 1.5(\mathrm{SF}): 1(\mathrm{AF})$, as well as a decrease in the average density in the ratio of $8(\mathrm{FH}): 7(\mathrm{LF})$ : 5(UF) : 4(SF) : 1(AF) (Fig. 1). One can assume that the structure of wasps' communities in vegetation zones of the Tatras represents the optimal dynamics of the species distribution and relations dominating in the high mountains of Poland. This assumption is supported by the not-devastated area of Tatra forests, as well as by the research season (the season when the number of Vespinae increased), during which the structure of communities was determined.

The studied Vespinae communities in Karkonosze changed its structure under the influence of new habitat conditions (Fig. 2). They changed it particularly in connection with climatic conditions as well as spatial organization of vegetation zones. It was revealed that the organization of subalpine forests, disturbed by clearings, significantly affected the increase of general species diversity of ( $\left.\mathrm{H}^{\prime}\right)$ Vespinae. Also a significant absolute increase in the density of wasps was recorded in the lower subalpine forest (LF). As for the community from the upper subalpine forest (UF), it was found that it preserved its quantitative potential similarly to the quantitative potential of the community from the upper subalpine Tatras forest.

Whereas, the distribution of the species' number in the communities from the zones of the Karkonosze Mts. was still at the similar ratio as the distribution of the species' number in the communities from the Tatras' zones. Taking this into account, as well as the specific dynamics of the species count, one can state that general changes in the dynamics of the structure of Vespinae communities represent a transitional nature of changes taking place in the reorganized subalpine forests of the Karkonosze Mts. Further succession changes of substitute habitats on clearings of spruce forests should reduce more and more their habitat attractiveness for social wasps. At the same time, the decline in attractiveness should be most perceptible in the lower subalpine forest. Finally, as the reconstruction of subalpine forest stands proceeds in the Karkonosze Mts., their communities of social wasps should establish the dynamics of the structure of Vespinae communities from the high mountains of the Meadle Europe. 


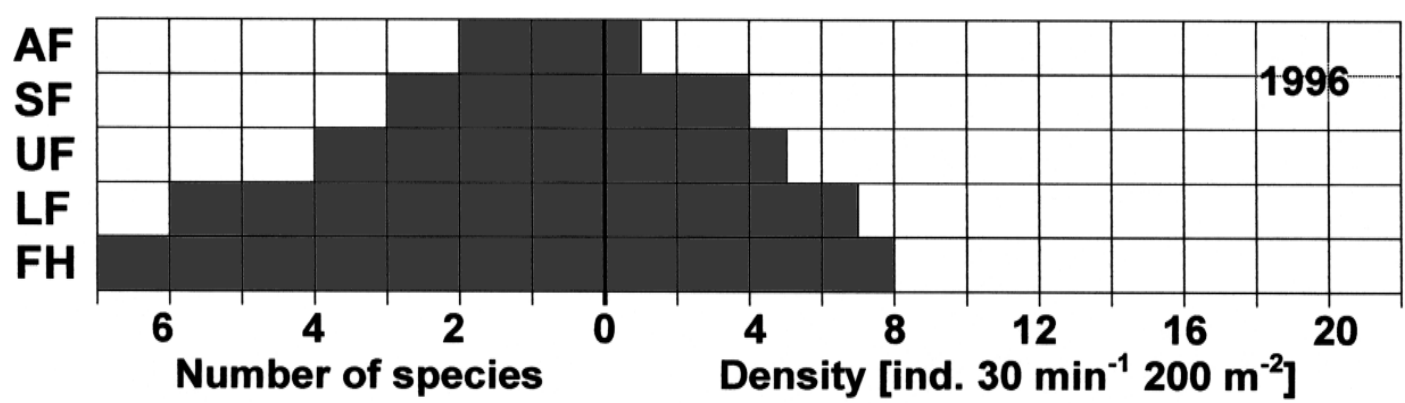

Figure 1. Qualitative and quantitative changes in the structure of communities of vegetation zones in the Tatra Mts. determined in 1996 (materials according to Pawlikowski 1997); FH - foothills; LF - lower sprurce forest; UF - uper sprurce forest; SF - subalpine floor; AF - alpine floor

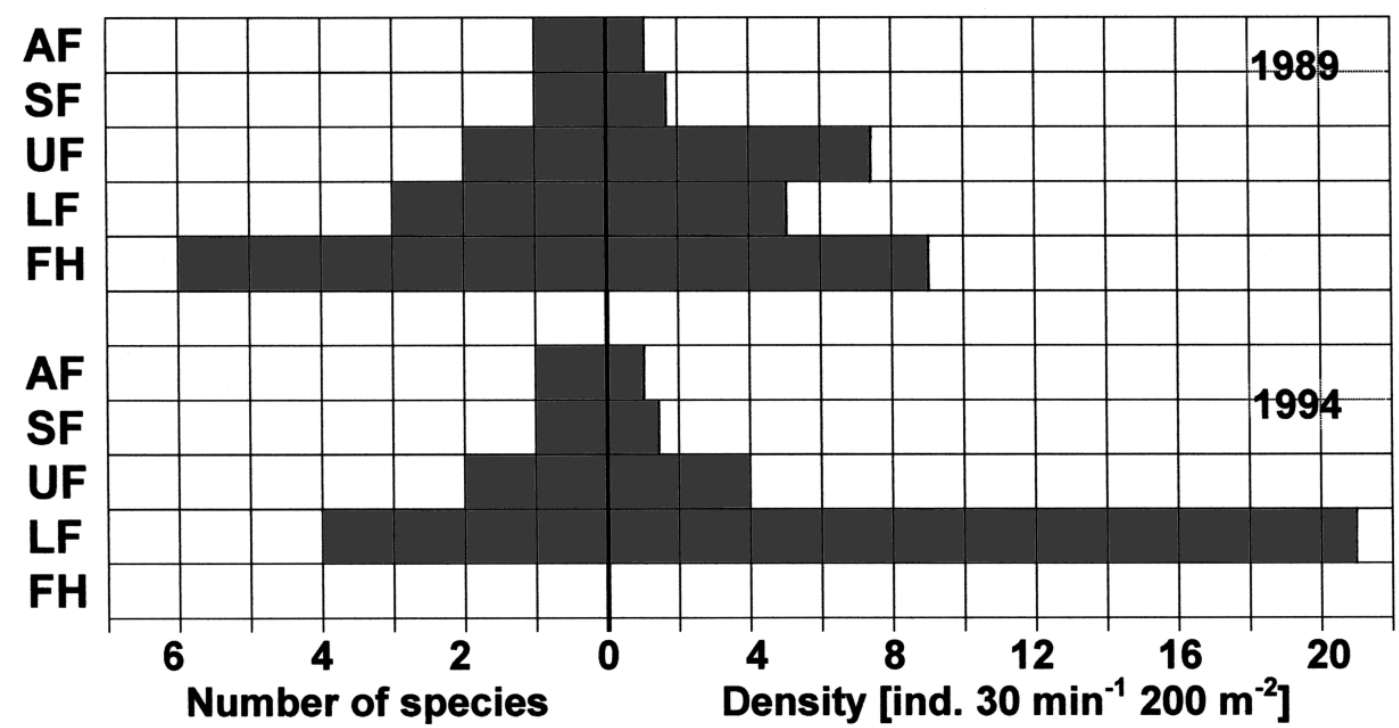

Figure 2. Qualitative and quantitative changes in the structure of communities of vegetation zones in the Karkonosze Mts. determined in 1989 and 1994; FH - foothills; LF - lower sprurce forest; UF - uper sprurce forest; SF - subalpine floor; AF - alpine floor

\section{References}

Archer M. E., 1998, A lifetime with wasps (Hymenoptera: Vespinae), Naturalist 123: 3-14.

Edwards R., 1980, Social wasps, Their biology and control, Rentokil, East Grinstead.

Fabiszewski J., 1985, Szata roślinna [Vegetation cover], [in:] A. Jahn (ed.), Karkonosze Polskie [Polish Karkonosze Mountains], PWN, Wrocław: 191-235.

Hutcheson K., 1970, A test for comparing diversities based on the Shannon formula, I, Theor. Biol. 29: 151-154.
Kemper H. \& Dőhring E., 1967, Die sozialen Faltenwespen Mitteleuropas, Verlag, Berlin-Hamburg.

Matsuura M. \& Yamane S., 1990, Biology of the Vespinae wasps, Springer-Verlag, Berlin-London-Tokyo.

Pawlikowski T., 1990, Wasp communities (Hymenoptera, Vespidae) in agricultural landscape of Chełmno Land (N Poland), Pol. Pismo Ent. 60: 115-128.

Pawlikowski T., 1993, Materiały do studiów nad strukturą zespołów żądłówek (Hymenoptera, Aculeata) Polski. 2. Osy społeczne (Vespinae) wschodnich Karkonoszy [Materials to study the community structure of 
Hymenoptera Aculeata in Poland. 2. Social wasps (Vespinae) of the Eastern Karkonosze Mts.], Wiadom. Entomol. 12 (1): 41-44.

Pawlikowski T., 1997, Materiały do studiów nad strukturą zespołów żądłówek (Hymenoptera: Aculeata) Polski. 8. Osy społeczne (Vespinae) polskich Tatr [Materials to study the community structure of Hymenoptera Aculeata in Poland. 8. Social wasps (Vespinae) of the Polish Tatry Mts.], Wiadom. Entomol. 16 (1): 29-30.

Pawlikowski T. \& Osmański M., 1998, Atrakcyjność środowisk miejskich dla os społecznych (Hymenoptera: Vespinae) na obszarze Torunia [Attractiveness of city environments for social wasps (Hymenoptera: Vespinae) in the area of Toruń], Wiadom. Entomol. 17 (2): 95-104.

Pawlikowski T. \& Przybylska E., 2001, Dynamika zmian struktury zespołu os społecznych (Hymenoptera: Vespinae) na obszarze Torunia w latach 1979-1995
[Dynamics of structure changes of the social wasp community (Hymenoptera: Vespinae) in the town area of Toruń during 1979-1995], [in:] Bioróżnorodność i ekologia populacji zwierzęcych w środowiskach zurbanizowanych [Biodiversity and ecology of animal populations in urbanized environments]: NICE, Bydgoszcz: 94-101.

Pawlikowski T. \& Pawlikowski K., 2006, Long-term dynamics of structure changes of the social wasp community (Hymenoptera: Vespinae) in agricultural landscape of the Kujawy Region, Ecological Questions 7: 21-28.

Pielou E. C., 1966, Shannon's formula as a measure of specific diversity: its use and misuse, Amer. Naturalist 100: 463-465.

Shannon C. E. \& Weaver W., 1963, The mathematical theory of communication, University of Illinois Press, Urbana. 